\title{
DINAMIKA UNI EROPA: Integrasi Kawasan dan Referendum Britania Raya
}

\author{
Riska Luneto ${ }^{1}$ \\ ${ }^{1}$ Program Hubungan Internasional Fakultas Ushuluddin dan Filsafat UIN \\ Alauddin Makassar \\ riska.luneto@uin-alauddin.ac.id
}

\begin{abstract}
European Union is a form of regional interdependence based on a common identity within a region. The $E U$ as a regional institution and a new actor in international politics has become a party that plays an important role in regional interaction and cooperation. In this paper, the author tries to explain the dynamics of regional cooperation that is formed by the EU based on the concept of regional integration from several perspectives, the existence of a common identity, the need for economic improvement to development are several reasons related to the birth of a regional integration. On the one hand, for approximately 60 years the EU has been running, problems have arisen when the UK has held a referendum since 2015, the choice to leave the EU was deemed necessary because Britain faces various problems related to sovereignty, immigrants and the problems of the crisis that the EU is experiencing.
\end{abstract}

Keywords: Integration, regional, domestic, sovereignty, asylum, European Union.

\section{Pendahuluan}

Tradisi berfikir tradisional dalam Hubungan Internasional cenderung berfokus pada negara sebagai aktor tunggal dan juga representasi pada arena politik global, keberadaan individu, institusi serta actor baru dalam politik global kemudian berkembang setelah interaksi dan isu dunia internasional tidak lagi hanya terikat pada negara semata (Jackson and Sorensen 2003). Keberadaan globalisasi dimana hilangnya batas dan berkembangnya ruang gerak actor juga menandai munculnya isu-isu kontemporer dengan aktor baru yang beragam. 
Dalam perkembangan hubungan internasional, aktor-aktor dalam kajian ini semakin berkembang, tidak hanya terletak pada negara, melainkan aktor non-state yang juga memiliki peran penting dalam politik internasional, dimana hal ini berbanding terbalik dengan traditional theory yang selalu menganggap bahwa negaralah aktor yang berkuasa penuh dalam melakukan interaksi transnasional. Aktivitas-aktivitas politik tidak lagi bermain pada arena domestik semata, melainkan ada peran yang dimainkan oleh aktor lain secara internasional (Barkin 2006).

Kerjasama internasional baik yang dijalin secara global maupun regional kemudian menjadi pembahasan baru dalam dunia internasional, hingga menimbulkan perdebatan, apakah kerjasama di bawah sebuah institusi tetap dapat mempertahankan kedaulatan setiap negara anggota sebagaimana negara sebagai main actor dalam politik internasional, namun ada yang berpendapat bahwa kehadiran globalisasi yang kemudian lambat laun menjadikan posisi negara tergantikan oleh institusi tersebut (Barkin 2006).

Dalam sebuah kerjasama di bawah institusi/organisasi cukup berdampak pada arah dan kebijakan negara dalam berinteraksi, di satu sisi sebuah kerjasama memberikan dampak positif bagi negara anggota yang terlibat, namun disisi lain hal penting yang perlu digaris bawahi adalah peran dan kedaulatan negara dalam kerjasama dalam setiap kebijakan yang dibuat bersama. Sebagai sebuah kerjasama kawasan, Uni Eropa (UE) dibentuk tahun 1957 yang diawali pada sebuah kerjasama dalam bidang coal and steel dibawah perjanjian Roma (Treaty of Rome) yang diprakarsai oleh Prancis, Belgia, Italia, Luksemburg, Netherland dan Jerman (Zaidi, et al. 2017). UE adalah kerjasama kawasan yang memfasilitasi pembangunan melalui kerjasama single market dalam barang, jasa dan berbagai hal lainnya. Selain itu, kerjasama ini juga menggunakan mata uang sama sebagai bentuk kesepakatan dalam perdagangan tersebut.

Tahun 1960-an Inggris, sebanyak dua kali berusaha bergabung dengan UE, namun ditolak oleh Presiden Prancis Charles de Gaulle, yang melihat bahwa bergabungnya Inggris akan melemahkan suara Prancis dalam UE (UK 
Parliament 2013). Hingga pada tahun 1973 di bawah Perdana Menteri Edward Heath, Inggris bergabung dengan European Economic Community (EEC). UE memiliki beberapa institusi yang menangani beberapa bidang, diantanya; European Union Council, European Court of Justice, European Commission, European Central Bank, European Parliament dan European Court of Auditors.

Perjalanan UE sebagai sebuah institusi besar yang beranggotakan negara-negara dengan kepemilikan perekonomian tinggi, tidak serta membuat negara anggota mendapatkan keuntungan penuh dari kerjasama tersebut. Permasalahan yang kemudian menyita perhatian dunia internasional terhadap UE adalah krisis finansial tahun 2000, yang secara umum dipengaruhi adanya tingginya hutang yang meningkat signifikan, ditahun yang sama juga adanya pengenalan mata uang baru Euro, bagi negara anggota (Beker 2014). Permasalahan hutang ini kemudian menyebar pada beberapa negara, Yunani, Portugal, dan Irlandia yang kesulitan membayar hutang negaranya.

Disamping itu, permasalahan lain yang juga menjadi perbincangan dunia internasional adalah referendum Inggris yang mulai diberitakan sejak kepemimpinan David Cameron sebagai Perdana Menteri Inggris. Pembahasan Article 50 perjanjian UE mengenai proses pengunduran diri sebagai anggota dimulai pada tahun 2015-2016 dengan berbagai diskusi panjang antar elemen pemerintah, alasan kuat terkait pengunduran Inggris sebagai anggota kerjasama kawasan adalah adanya isu ekonomi dan imigran yang mewarnai perjalanan Uni Eropa (Somai and Biedermann 2016).

\section{Integrasi Regional}

Joseph S Nye dalam International Regionalism sebagaimana yang dikutip oleh Budi Winarno bahwa regionalisme dijelaskan melalui 5 kategori; regionalization, regional awareness and identity, regional interstate cooperation, state promoted regional integration dan regional cohesion (Winarno 2014). Kelima kategori ini merujuk pada kesadaran akan sebuah interaksi yang dilatarbelakangi oleh persamaan identitas dalam sebuah kawasan, serta 
menjalin kerjasama ekonomi, sosial, budaya dan politik dalam sebuah kawasan.

Ernst B. Haas dalam konsep Neofungsionalisme menjelaskan bahwa integrasi kawasan Uni Eropa adalah bentuk kerjasama kawasan yang menjelaskan bagaimana sebuah negara dalam suatu kawasan secara sukarela melakukan penyatuan konsep pemerintahan ataupun kerjasama dalam berbagai hal tertentu (Haas 1958). Keberadaan UE dengan institusi-institusi di dalamnya iniliah yang menjadi landasan negara anggota menjadikannya sebagai wadah untuk berinteraksi satu sama lain bahkan kerjasama UE dengan pihak luar. Integrasi UE tergolong cukup beragam, bagaimana mereka menyepakati kerjasama ekonomi dalam konsep perdagangan bebas/single market, single currency, serta kesepakatan dalam menangani isu-isu kemanusiaan seperti asylum seekers.

Faktor-faktor pendorong integrasi kawasan UE sendiri diantaranya; ekonomi (cost-benefit calculation), nilai dan identitas serta informasi (Sampson 2018). Keuntungan ekonomi, identitas kawasan serta informasi dalam sebuah kerjasama, menurut Sampson adalah gambaran nyata dari adanya sebuah integrasi kawasan, contohnya saja dalam Perang Dunia II tahun 1939-1945 meninggalkan berbagai masalah yang berkelanjutan di berbagai negara, khususnya negara-negara yang terlibat langsung dalam peperangan tersebut, di tahun-tahun setelahnya negara-negara kawasan Eropa juga masih berusaha pulih dan bangkit pasca PD II.

Dalam berbagai sektor diupayakan oleh pemimpin negara untuk kembali normal bahkan dapat lebih baik lagi, sebagai upaya pembangunan kembali, khususnya negara di kawasan Eropa sendiri melakukan kerjasama dalam bidang ekonomi, politik dan berbagai hal lain, Prancis sebagai salah satu negara yang kemudian memprakarsai terbentuknya kerjasama di kawasan Eropa. Sebagai sebuah kerjasama kawasan, pembentukan Uni Eropa (UE) diawali dengan Deklarasi Schuman disampaikan oleh Menteri Luar Negeri Perancis Robert Schuman pada tanggal 9 Mei 1950. 
Deklarasi ini mengusulkan pembentukan European Coal and Steel Community (ECSC) dengan negara pendiri lainnya: Prancis, Jerman, Italia, Belanda, Belgia, dan Luksemburg, yang kemudian menjadi cikal bakal berdirinya institusi supranasional Eropa dengan nama Uni Eropa saat ini (Department of State 1951). Keenam negara ini kemudian menandatangani kesepakatan dalam Treaty of Paris tahun 1951, serta pembentukan komisi dalam ECSC yaitu; High Authority, Common Assembly, Special Council dan Court of Justice.

Keanggotaan ECSC terbuka untuk negara Eropa lainnya, perkembangan kerjasama ini mengalami peningkatan dalam berbagai bidang lainnya, pada tahun 1957 dalam Treaty of Rome dibentuk kerjasama dalam bidang ekonomi, atau yang dikenal dengan European Economic Community. Inggris kemudian bergabung dengan UE pada tahun 1973 diikuti beberapa negara lain. Tahun 1993 UE kemudian menyepakati konsep Single Market yang membawahi kerjasama dalam bidang barang, jasa, SDM dan moneter secara bebas (European Union 2020).

Kerjasama kawasan sendiri, menurut Acharya dan Stubbs dipengaruhi oleh adanya security community antar negara kawasan, (Acharya and Stubbs 2006). Menciptakan lingkungan yang aman antar negara dirasa perlu, selain sebagai upaya atau kecenderungan untuk mengurangi peperangan/konflik juga menciptakan perdamaian dalam sebuah komunitas atau kawasan. Dalam perspektif Ayoob dia menambahkan bahwa interaksi yang dijalin oleh negara-negara dalam sebuah wilayah regional adalah penggabungan dari pandangan realisme klasik, studi historical sociological dari pembangunan sebuah negara serta pandangan dari perspektif English School dalam memandang sebuah kerjasama (Ayoob 2002).

Penggabungan perspektif ini yang kemudian dijadikan landasan oleh Ayoob untuk melihat kerjasama kawasan, menurutnya negara berkembang relatif 'lemah', mereka masih cenderung sibuk dalam membangun identitas nasional sehingga kesadaran akan pentingnya sebuah institusi non domestic berdasarkan persamaan budaya dan sejarah yang memiliki kesamaan 
dibutuhkan guna menyikapi interaksi yang anarki dan menjadi pihak yang membawahi dan membuat aturan-aturan kerjasama dan penyelesaian sengketa.

Dalam realisme klasik Machiavelli \& Hobbes, hal yang paling ditekankan adalah menciptakan struktur politik domestik yang stabil di negara asal mereka. English School juga menekankan berbagai kerjasama yang dimungkinkan antar negara berdaulat dalam sistem internasional (Linklater and Suganami 2009), meskipun negara-negara ini masih berupaya membangun struktur politik yang kuat dalam politik internasional yang anarki, kerjasama dan latar belakang historical sociological yang kemudian mengeratkan hubungan tersebut. Sehingga, disimpulkan bahwa ketiga perspektif ini cenderung memberikan alasan tepat untuk melihat upaya kerjasama yang dilakukan oleh negara berkembang pada khususnya.

Pada prinsipnya, dalam sebuah integrasi regional terdapat beberapa alasan penting yang menjadi landasan negara-negara ini bergabung secara sukarela dalam sebuah regional; adanya latar belakang yang memiliki kemiripan, mulai dari sejarah, kesamaan terhadap apa yang dialami pada masa lampau serta kesamaan nasib yang dirasakan yang kemudian menimbulkan identity yang sama dengan negara kawasan lainnya (Fawcett and Hurrel 1995). Kita tahu bahwa Uni Eropa lahir pasca PD II, dimana hampir seluruh wilayah tersebut merasakan dampak langsung dari konflik yang berlangsung, sehingga keinginan untuk berbenah diri pasca terjadinya konflik menjadi salah satu alasan. Konsep lainnya yang melatar belakangi lahirnya integrasi regional adalah keadaan geografis negara, integrasi yang terjalin dalam sebuah kawasan tidak lepas dari kedekatan geografis suatu negara, yang terakhir adalah keinginan negara untuk memiliki dan menciptakan aturan dalam interaksi dan hubungan suatu kawasan (Tidore 2017)

Berbeda dengan pendapat Hedley Bull (Barkin 2006) juga menjelaskan mengenai kerjasama dijalankan berdasarkan tiga perspektif berbeda, yaitu Realist yang masih bersifat tradisional dalam memandang actor lain selain 
negara, mereka melihat dunia internasional merupakan situasi anarki, yang dapat membatasi pergerakan dan interaksi, kecuali kekuatan negara lain, realisme cenderung skeptis dalam melihat peran organisasi/institusi, menurut mereka power adalah keunggulan yang hanya dimiliki oleh negara dimana negara yang mampu mengontrol kekuatan besar seperti politik, ekonomi dan militer, berbeda dengan organisasi global maupun regional yang bergantung pada kepentingan negara dengan power besar.

Bagi kaum realis, organisasi yang dibentuk merupakan alat bagi negara-negara untuk merealisasikan keinginan atau national interest-nya masing-masing bukan sebagai aktor utama. Negara tetap pada tempatnya sebagai aktor yang memiliki 'power' dalam sistem internasional. Negara besar tidak akan kehilangan otonominya terhadap sebuah institusi/organisasi, karena tidak dipungkiri negara besar atau negara yang memiliki power inilah yang membuat organisasi tersebut. Negara kecil/lemah dan sedikit power terkadang memiliki keterbatasan terhadap kekuasaan sebuah organisasi.

Perspektif Bull lainnya ialah Tradisionalis, yang melihat negara sebagai aktor utama namun dengan mempertimbangkan perilaku sosial dalam sebuah interaksi, "we can't understand international politics without looking at those rules. IOs become the expressions of the rules that govern international society" (Barkin 2006). Tradisi ini melihat adanya aturan-aturan yang ikut berperan dalam lingkungan internasional, negara tidak akan bisa mengikuti pergerakan dan perkembangan politik internasional tanpa sebuah aturan yang mengikat, sehingga bagi mereka keberadaan institusi/organisasi juga memiliki peran signifikan yang turut serta membuat aturan-aturan main dalam berinteraksi, meskipun bagi mereka negaralah aktor yang paling utama dalam membuat aturan politik internasional. Selain itu, bagi mereka perkembangan globalisasi kedepannya akan mengurangi peran negara yang memiliki kedaulatan untuk melakukan berbagai interaksi global.

Pemikiran Bull yang ketiga adalah, Universalism. Tradisi berfikir ini cenderung berbeda dengan kedua konsep yang telah dijelaskan sebelumnya, dimana universalisme melihat langsung pada aktor individu dari pada 'negara' 
(non state-centric). Bagi mereka, negara cenderung bersifat kaku, yang terkadang dibatasi oleh norma yang berkembang di masyarakat, peran negara juga seringkali tidak relevan dalam membangun masyarakat global. Sehingga, mereka berkesimpulan bahwa institusi/organisasi adalah aktor penting yang mampu menciptakan tatanan masyarakat global dibandingkan sebagai pembuat aturan antar negara seperti pemikiran tradisionalis.

\section{Globalisasi dan integrasi kawasan}

Interaksi antar bangsa dalam arena politik global mencakup beberapa bidang kerjasama didalamnya. Kerjasama ini kemudian melahirkan upaya penyatuan/integrasi wilayah, ekonomi dan berbagai kerjasama lainya. Hadirnya globalisasi kemudian menjadi salah satu faktor berkembangnya interaksi antar bangsa, globalisasi politik, ekonomi bahkan budaya kerap menjadi perbincangan pihak internasional. Globalisasi kemudian erat kaitanya dengan integrasi regional yg dilakukan oleh negara-negara kawasan, upaya kerjasama dilaksanakan dengan dasar persamaan sejarah, identitas, serta memiliki prinsip non intervention juga hormat terhadap kedaulatan dan otoritas suatu negara.

Dalam perkembangan yang ada, dinamika politik internasional yang semakin kompleks menjadi tantangan akan kedua hal tersebut, bentuk kerjasama yang dijalin dalam payung integrase serta perkembangan globalisasi yang sangat pesat seringkali menjadi tantangan actor terkait kedaulatan dan otoritas penuh akan kendali politik domestic dan internasional suatu negara. Dalam beberapa contoh kasus, permasalahan yang menjadi pertanyaan sebagian pihak adalah otoritas institusi kerjasama dan negara dalam melakukan interaksi dan menyikapi permasalahan yang dihadapi.

\section{Inggris dan Uni Eropa}

Britania Raya (Inggris, Skotlandia, Wales dan Irlandia Utara) bergabung dengan Uni Eropa Pada tahun 1973, bergabungnya Inggris dalam keanggotaan UE dipengaruhi oleh keberhasilan European Coal and Steel Community dalam 
membangun dan meningkatkan perekonomian pasca perang dunia II. Sebelum resmi bergabung pada tahun 1973, Inggris telah lebih dulu merekomendasikan diri sebelumnya, namun mengalami penolakan sebanyak 2 kali oleh Prancis. Bergabungnya Inggris dengan UE cukup berdampak signifikan terhadap perekonomian domestik Inggris, meningkatnya PDB Inggris serta terbukanya pasar bagi Inggris di kawasan UE.

Sebagai organisasi kawasan, UE memberikan kemudahan bagi negara anggota untuk melakukan interaksi dan kerjasama dalam berbagai bidang; perdagangan, investasi, pendidikan, izin tinggal dan berbagai hal lainnya. Kerjasama Inggris dalam kawasan UE tidak serta menghalangi keinginan Inggris untuk keluar dari UE, pertengahan tahun 2016 Referendum Inggris pertama dilaksanakan oleh David Cameron sebagai Perdana Menteri Inggris sejak tahun 2012 untuk menentukan keanggotaannya dalam UE apakah memilih untuk bertahan atau keluar. Referendum ini kemudian dikenal dengan istilah Brexit (British Exit).

\section{Referendum Britania Raya}

Kerjasama UE memberikan dampak yang cukup signifikan terhadap negara anggota baik dalam pengaruh politik, sosial bahkan ekonomi. Dalam kerjasama ekonomi, misalnya, negara-negara yang tergabung dalam institusi tersebut memiliki keuntungan dan kemudahan dalam pengembangan ekonomi. Adanya kesepakatan single market yang berlaku bagi negara anggota, dimana hilangnya hambatan perdagangan dengan konsep free trade sangat terasa antar negaranya, single market sendiri bertujuan menstimulasi perdagangan dan peningkatan efisiensi dan kualitas produk serta meminimalisir hambatan yang menjadi instrumen dalam kerjasama ekonomi dan perdagangan (European Community 2019), data dibawah ini memperlihatkan perbandingan GDP UE dengan negara-negara lain, serta GDP UE dalam International Monetary Fund. 


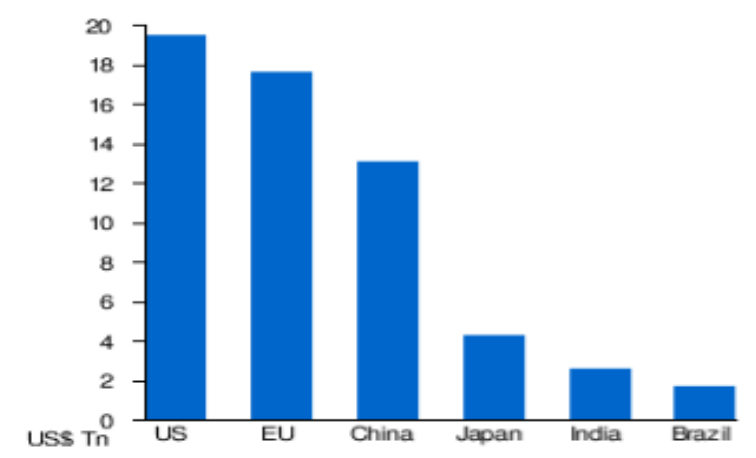

Sumber: (Zaidi, et al. 2017)

Gambar 2. GDP-IMF 2015

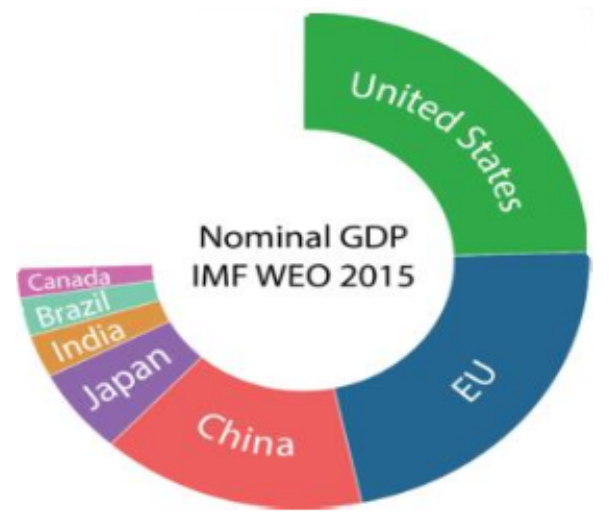

Sumber: (Zaidi, et al. 2017)

Disatu sisi, perkembangan kerjasama yang ada justru tidak dirasakan dan memberikan dampak positif oleh Inggris, sehingga pemerintah Inggris sejak tahun 2016 mengeluarkan putusan untuk mempertanyakan keanggotaanya dalam UE atau memilih keluar dari keanggotaan. Selain permasalahan tersebut, isu lain yang juga menjadi pemicu referendum tersebut adalah isu imigran dalam politik Inggris, isu imigran menjadi beban tersendiri bagi Inggris ketika adanya pergerakan terkait kebebasan bergerak bagi setiap imigran yang masuk (UK Essays 2018). Sebelum referendum sendiri, Inggris termasuk dalam salah satu negara dengan jumlah imigran terbesar jika dibandingkan dengan negara anggota lainnya yang juga memiliki pengaruh besar dalam European Council. 
Secara umum, referendum Inggris dikategorikan dalam beberapa alasan diantaranya; krisis anggaran dan ekonomi, isu-isu terkait imigran serta adanya pertanyaan terkait kedaulatan Inggris sebagai sebuah negara merdeka yang merasa peran dan fungsinya mengalami kelemahan. Pada dasarnya, UE memberikan kewenangan dan otoritas penuh terhadap negara anggota yang memiliki kebijakan independen dalam bidang moneter, seperti dalam devaluasi nilai mata uang mereka dan memberikan otoritas menyikapi krisis secara independen, hal ini bisa kita lihat pada krisis Yunani yang terjadi tahun 2009 (Park, Castillejos-Petalcorin and Kim 2020).

Tabel 1. Brexit Timeline

\begin{tabular}{|c|l|}
\hline Tahun & \multicolumn{1}{|c|}{ Proses } \\
\hline 1961 & Inggris bergabung dengan EEC \\
\hline 1967 & Keanggotaan kedua \\
\hline 1975 & Negosiasi terkait pengurangan anggaran ECC \\
\hline 1990 & Exchange Rate Mechanism \\
\hline 1992 & Maastricht Treaty, leaves ERM \\
\hline 1997 & Amsterdam Treaty \\
\hline 2011 & $\begin{array}{l}\text { Revisi David Cameron terkait Perjanjian Lisbon } \\
\text { (melindungi sektor finansial Inggris }\end{array}$ \\
\hline 2013 & Diskusi Referendum \\
\hline 2015 & Partai konservatif \\
\hline Feb 2016 & Special status - David Cameron \\
\hline Juni 2016 & Britain vote for Brexit \\
\hline Juli 2016 & Theresa May diangkat sebagai PM \\
\hline 2017 & Pembahasan artikel 50 UE \\
\hline Juli 2018 & Chequers Plan \\
\hline Nov 2018 & UE menyetujui negosiasi \\
\hline Des 2018 & Theresa May memenangkan 200 votes \\
\hline Jan 2019 & Komentar The House of Commons terkait Brexit \\
\hline Mar 2019 & Batas akhir diskusi ke 2 Brexit \\
\hline
\end{tabular}




\begin{tabular}{|l|l|}
\hline Juli 2019 & Boris Johnson sebagai PM \\
\hline Jan 2020 & Batas akhir diskusi ke 3 Brexit \\
\hline
\end{tabular}

Sumber: (Park, Castillejos-Petalcorin and Kim 2020)

\section{Sovereignity}

Kerjasama internasional yang dijalankan oleh sebuah kawasan maupun secara global bertujuan untuk dapat menangani dan meminimalisir permasalahan yang ada, selain itu kerjasama tersebut tidak lain adalah sebagai wadah dalam realisasi kepentingan nasional dalam sebuah kesepakatan bersama. Sebuah organisasi dengan hak dan wewenangnya dalam menjalankan aturan bersama, seringkali menimbulkan pertanyaan lebih lanjut, sejauh mana hak sebuah institusi untuk dapat berperan dalam sebuah keadaan. Dalam Hukum Internasional, kedaulatan sebuah organisasi erat kaitannya dengan peradilan dalam sebuah sengketa antar negara anggota, dimana ketika sebuah negara tidak dapat menyesuaikan atau mengikuti aturan internasional, maka pihak luar memiliki tanggung jawab dalam mengintervensi (Lombok 2014).

Kedaulatan sebuah organisasi/institusi didapatkan adalah didasarkan pada kepentingan anggota, bukan secara individu dalam organisasi tersebut, dalam sebuah kerjasama dibentuk kesepakatan dan perjanjian yang mengatur segala urusan rumah tangga dan disepakati bersama oleh keseluruhan anggota, yang hal ini jika dikaitkan dengan konsep kedaulatan tradisional mengalami penambahan makna, dimana kedaulatan adalah sebagai bentuk tanggung jawab bersama bagi negara anggota (Lombok 2014).

Dalam pandangan kaum realis, national interest menjadi sebuah elemen untuk mencapai kepentingan mendasar setiap negara; ekonomi, politik dan militer, dengan sebuah interaksi yang dibangun baik dalam sebuah kawasan maupun secara global. Selain itu, bagi kaum realis, national interest seringkali juga dianggap sebagai upaya untuk mencapai power yang nantinya dapat digunakan sebagai alat untuk memelihara control dalam interaksi antar 
bangsa serta mempertahankan kedaulatan sebuah negara (Jackson and Sorensen 2003). Morgenthau berpendapat bahwa kepentingan nasional dibangun atas factor-faktor tertentu, seperti kebutuhan dasar suatu bangsa serta keinginan untuk dapat mempertahankan negara dalam arena politik global (Morgenthau 1951).

Referendum Inggris yang dilakukan sejak tahun 2016, kemudian oleh beberapa pihak dinilai bahwa Inggris mulai kehilangan kedaulatan negaranya dalam melakukan interaksi. Integrasi kawasan UE kemudian menimbulkan pertanyaan bagi sebagian peran negara anggota mengenai kedaulatan dan kemampuan untuk menentukan kebijakan negaranya dalam berperilaku dalam dinamika internasional. Kedaulatan nasional Inggris dalam beberapa dekade semakin mengalami penurunan eksistensi yang disebabkan entitas supranasional baru

Perumusan kebijakan dalam UE dinilai mengesampingkan peran dan kemampuan negara anggota lain, hal ini dilihat dari beberapa adopsi kebijakan yang disepakati namun tidak mampu diterapkan dan dijalankan oleh sebagian negara anggota. Open Door Policy adalah salah satu bentuk kesepakatan yang dikeluarkan UE dalam menangani isu imigran, setiap negara anggota dengan secara terbuka untuk dapat menerima imigran yang masuk kedalam wilayah Eropa yang dilatarbelakangi oleh kesepakatan internasional terkait imigran. Inggris dan Prancis adalah contoh dari dua negara yang kemudian mengalami kesulitan dalam mengintegrasikan pendatang dengan segala aturan dan kebijakan dalam negerinya (Eremina and Chikhachev 2016). Permasalahan yang kemudian muncul khususnya yang terjadi di Inggris seperti munculnya kelompok-kelompok anti-imigran menjadi boomerang tersendiri bagi masyarakat Inggris dan imigran yang masuk

Pemerintah Inggris dan Prancis harus menemukan keseimbangan antara kebijakan negara dan imigran untuk dapat memastikan keamanan yang meningkat tidak hanya bagi masyarakat lokal melainkan bagi pendatang. Kebijakan open door migration sendiri menyebabkan meningkatnya kuantitas pendatang bagi negara-negara anggota UE, dengan peningkatan ini dinilai 
dapat mengarah pada dimensi keamanan nasional sehingga diperlukan prioritas kebijakan lainnya dalam kawasan UE selain pada kebijakan imigran tersebut. (Eremina and Chikhachev 2016).

Pemilihan untuk menarik diri UE didasari oleh permasalahan perekonomian domestik Inggris yang cenderung kurang bervariatif. Sebagai negara dengan kekuatan ekonomi besar Inggris hanya fokus pada negara berkembang, sebagian besar interaksi perdagangan hanya dilakukan dengan negara anggota UE. Pengeluaran Inggris dalam biaya keanggotaan UE juga dinilai tidak sebanding dengan feedback dan keuntungan yang dirasakan Inggris.

Gambar 1. Perbandingan GDP UK-UE

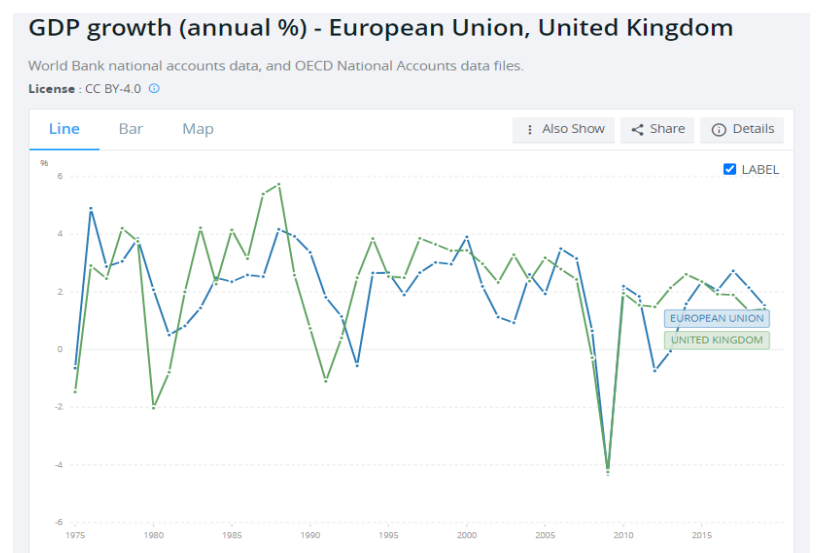

Source: data.worldbank.org

\section{Migrants Crisis}

Pilihan Inggris untuk menarik diri dari UE pada awal tahun 2020 sudah menjadi isu sejak David Cameron (PM Inggris) merancang referendum Inggris pada tahun 2015, referendum ini kemudian disepakati setelah melalui proses pro-kontra antar kedua kubu yang ada. Salah satu alasan untuk menarik diri dari keanggotaan UE bagi sebagian pihak adalah isu dan penanganan imigran yang masuk ke wilayah UE khususnya Inggris (Somai and Biedermann 2016). Perpindahan penduduk yang terjadi secara besar-besaran cukup menarik perhatian dunia internasional, hal ini mengingat dapat mempengaruhi stabilitas sebuah negara, jika tidak dikontrol dengan baik. Selain itu, 
perubahan dan perkembangan jumlah penduduk suatu negara dapat mengancam keamanan suatu negara.

Sebagai sebuah institusi internasional, UE mengadopsi kebijakan Konvensi Jenewa mengenai permasalahan asylum seekers (imigran dan pengungsi). Kebijakan ini kemudian dituangkan dalam Comman European Asylum Seekers (CEAS). Meningkatnya jumlah imigran di Inggris, menjadikan Inggris untuk memiliki kontrol penuh terhadap aturan jumlah kuota dan regulasi-regulasi penuh terkait migrasi. Jumlah populasi imigran yang masuk di Inggris sendiri lebih banyak dibandingkan negara-negara UE lainnya, Keputusan UE yang mengharuskan setiap negara anggota untuk mendukung kebijakan ramah imigran dan membuka pintu terhadap imigran asing melalui Open Door Policy. Kebijakan ini dibentuk oleh European Commission yang dimaksudkan untuk semua negara anggota ikut bertanggung jawab terhadap permasalahan imigran di kawasan tersebut. CEAS dibentuk dan disepakati sejak tahun 1999, dimana UE menginginkan sebuah aturan mengikat dan adil dalam menangani permasalahan suaka.

Seperti diketahui UE mendukung penuh kesepakatan global mengenai isu imigran, hal ini kemudian secara tidak langsung berlaku bagi setiap negara anggota lainnya. Permasalahan ketidakmerataan jumlah imigran yang masuk di Inggris kemudian menimbulkan masalah baru, seperti masalah pengangguran, pendidikan, kesehatan, sebagian besar masyarakat Inggris menilai bahwa masuknya imigran dan terbukanya lebar pintu imigran menimbulkan korelasi terhadap penurunan pendapatan masyarakat yang mempengaruhi keinginan untuk meninggalkan UE.

Keberadaan globalisasi sekiranya memberi dampak cukup signifikan terhadap perkembangan dunia internasional; isu politik, ekonomi, sosial dan budaya. Isu ini kemudian cukup mempengaruhi arah kebijakan dan politik luar negeri suatu negara bahkan kebijakan negara kawasan. Globalisasi kemudian juga menimbulkan berbagai permasalahan baru dalam dunia internasional, isu-isu yang kemudian menjadi pembahasan bukan lagi seputar perang, militer dan konflik melainkan berkembang seperti pada perlindungan 
hak asasi manusia khususnya bagi korban perang ataupun pencari suaka yang menjadi pembahasan dalam beberapa tahun terakhir.

Permasalahan mengenai suaka menjadi sebuah isu yang cukup menarik perhatian dunia internasional. Dalam konvensi Jenewa, hal ini diartikan sebagai penganiayaan yang dikarenakan alasan agama, ras, kebangsaan pada kelompok tertentu, hal ini yang kemudian mempengaruhi individu tidak memiliki indentitas dan mencari perlindungan (UNHCR 1966). Pemberian suaka sendiri adalah hak bagi setiap individu, adopsi konvensi Jenewa bagi UE tertuang dalam konsep open door policy atau free movement (Common European Asylum Seekers (CEAS) dimana setiap negara anggota wajib membuka pintu bagi setiap individu yang membutuhkan perlindungan (Commission 2020). Dalam CEAS disepakati bahwasanya;

1. Adanya kesepakatan dan implementasi konvensi Jenewa mengenai imigran dan perlindungannya, sehingga dalam CEAS disebutkan bahwa negara anggota dapat membuka pintu negaranya terhadap imigran maupun pencari suaka.

2. Dukungan dan kerjasama antar negara anggota dalam menangani isu imigran khususnya bagi masyarakat yang terkena dampak perang/konflik di negara asalnya.

3. Solidaritas dan tanggung jawab bersama dalam merealisasikan konvensi dan perjanjian-perjanjian internasional.

Dalam kerjasama dan kesepakatan UE mengenai imigran sendiri menetapkan bahwa setiap pencari suaka diperlakukan dalam sebuah sistem yang adil dan terbuka. Memenuhi setiap hak dasar dan hak hidup untuk setiap pencari suaka tanpa melihat asal negara dan kondisi sosial mereka, selain itu kesepakatan ini juga melindungi pencari suaka secara penuh baik dalam kawasan regional maupun internasional (Commission 2020). Kementerian Luar Negeri Indonesia menyimpulkan bahwa dalam sebuah isu-isu kemanusiaan terkait dengan pencari suaka, disebabkan oleh konflik berkepanjang yang masih terjadi khususnya di wilayah Timur Tengah yang mengakibatkan meningkatnya jumlah penduduk yang terkena imbas dari 
konflik tersebut, masyarakat yang kehilangan kependudukannya dan berbagai permasalahan lainnya. Faktor lainnya yang juga mempengaruhi meningkatnya jumlah imigran adalah keberadaan bencana alam yang kemudian mempengaruhi geografis sebuah negara, dimana diantaranya masyarakat di suatu negara ada yang kehilangan wilayah tinggal, sehingga mengakibatkan mereka untuk berpindah tempat (Kemlu 2019).

Schengen Agreement sebagai salah satu kesepakatan Uni Eropa yang kemudian melahirkan Dublin Convention yang dinilai mengarah pada hilangnya batas-batas suatu negara di kawasan tersebut. Dalam konvensi Dublin mengatur bagaimana prosedur masuknya pencari suaka, bagaimana negara penerima memperlakukan setiap individu yang masuk, meskipun mengalami beberapa kali revisi dalam perjanjian ini, konvensi Dublin dibentuk dengan tujuan untuk memastikan tersedianya perlindungan bagi setiap individu yang membutuhkan khususnya bagi setiap pencari suaka serta pembagian merata jumlah kuota imigran yang masuk di Uni Eropa (Fratzke 2015), di satu sisi perjanjian ini yang kemudian memungkinkan masuk dan menyebarnya secara bebas pencari suaka di kawasan Uni Eropa, oleh karenanya kerjasama antar negara anggota Uni Eropa dalam menanggulangi permasalahan ini bergantung pada kebijakan bersama.

Berdasarkan UNHCR, jumlah pengungsi mengalami peningkatan besar pasca tahun 2011 secara global, hal ini dipengaruhi oleh pecahnya perang sipil di wilayah Suriah yang kemudian berdampak pada masyarakat Suriah memilih untuk meninggalkan wilayah tersebut. Pada tahun 2013 tercatat sebanyak 51,2 juta jiwa, tahun 2014 naik sebanyak 59,5 juta jiwa. Sementara jika dilihat 1 dekade sebelumnya UNHCR mencatat sekitar 37,5 juta jiwa (UNHCR 2015).

Selain Suriah, tercatat ada 2 negara lain yang juga turut menghasilkan jumlah pengungsi dan pencari suaka meningkat, Afghanistan 2,59 juta jiwa dan Somalia 1,1 juta jiwa, yang jika dilihat ketiga negara tersebut adalah mereka yang terkena dampak konflik politik domestic. Selain itu, sebagian besar pengungsi berasal dari negara yang masih berkekurangan atau tidak 
mampu mengontrol permasalahan serta membangun perekonomian negaranya (UNHCR 2015).

Keadaan negara asal ini yang kemudian menjadi salah satu alasan bagi para pencari suaka, pengungsi maupun imigran untuk keluar dan mencari tempat yang layak ke beberapa wilayah sekitar, seperti Eropa dan Australia. Penanggulangan pengungsi di wilayah ini dapat dikatakan lebih menjamin dibandingkan beberapa negara lainnya, Uni Eropa sendiri telah mengadopsi aturan dan kebijakan perlindungan bagi para pengungsi, pencari suaka yang masuk di wilayah tersebut.

Dalam aturan UE, setiap imigran ataupun pencari suaka yang masuk kedalam wilayah Eropa, diwajibkan untuk mengisi form sebagai bentuk pendataan diri bagi para pencari suaka, sebagian besar dari mereka memilih Inggris sebagai negara tujuan akhir mereka. Pakistan dan Syria adalah contoh negara yang banyak memilih Inggris sebagai negara tujuan dibandingkan negara lainnya (Independent 2015). Jumlah imigran yang tergolong tinggi di kawasan UE khususnya Inggris, Prancis, Jerman menjadi salah satu alasan Inggris mendorong pembahasan mengenai referendum, selain itu, dalam Charter of fundamental rights of the European Union yang merupakan sebuah kesepakatan bersama negara kawasan dalam menangani isu hak asasi manusia, akan tetapi pada kenyataannya adopsi kebijakan dan kesepakatan ini belum mampu dilakukan oleh seluruh negara anggota UE, terbukti pada tahun 2015 gelombang imigran di UE tergolong cukup tinggi.

\section{Pasca Britain Exit}

Referendum dan proses keluarnya Inggris hingga hari ini masih menimbulkan berbagai pertanyaan bagi banyak pihak, it goes right or wrong adalah hal yang belum mendapatkan jawaban pasti, beberapa pihak menilai bahwa referendum dapat berdampak positif maupun negatif bagi ekonomi \& politik kedua pihak (Holden 2018). UE sebagai kerjasama regional memiliki kebijakan tersendiri terkait interaksi yang dijalankan baik dengan negara anggotanya maupun kerjasama dengan negara diluar daripada UE, aturan dan 
kesepakatan yang mengikat inipun berdampak khususnya bagi negara anggota baik sebelum referendum maupun setelah referendum Inggris.

Selama kurang lebih 47 tahun keanggotaan Inggris di UE cukup berdampak terhadap berbagai aspek Inggris khususnya, akan tetapi keanggotaanya tersebut tidak seutuhnya menaungi potensi Inggris sebagai negara maju. Sebagian besar masyarakat Inggris pun menganggap bahwa negaranya akan lebih dapat mandiri dengan mengeluarkan diri dari keanggotaan UE. Selain itu, Inggris melihat bahwa pasca Brexit, UE akan mengalami dampak signifikan terkait jumlah anggaran, dimana Inggris adalah negara dengan sumbangan terbesar dibandingkan negara lain. Hal ini juga akan berdampak cukup besar terhadap Jerman sebagai negara kontributor terbesar UE, terlebih jika UE meminta Jerman untuk memberikan sumbangan anggaran lebih besar, selain itu permasalahan yang kemungkinan bisa saja dihadapi negara lain, khususnya negara dengan pendapatan devisa dibawah, adalah kenaikan jumlah sumbangan yang wajib dibayarkan negara anggota (UK Essays 2018).

Meskipun prediksi mengenai keluarnya Inggris dari UE masih menjadi tanda tanya, beberapa menilai bahwa hal ini dapat membawa perubahan besar khususnya bagi kerjasama perekonomian global, kedua pihak akan menjadi dua partner yang memiliki kekuatan bersaing, Inggris yang menyadari akan potensi ekonominya akan membangun koalisi dengan negara-negara yang sekiranya memiliki dampak positif bagi kemajuan negaranya bukan hanya pada keuntungan ekonomi, melainkan mencangkup isu-isu kontemporer lainnya, meskipun kita tahu bahwa pasca Brexit, Inggris masih berupaya bangkit dari permasalahan ekonomi khususnya, dimana negara berupaya kembali meningkatkan produktivitas dan investasi asing. Disatu sisi, UE dengan 27 negara anggota yang ada, berupaya mengembalikan dan menaikkan kembali eksistensi sebagai sebagai sebuah partner kerjasama dalam berbagai bidang dengan pihak luar

Tahun 2021 adalah awal yang baru bagi Inggris dan UE, bagi masyarakat Inggris kesepakatan yang dulu didapatkan ketika masih menjadi 
negara anggota UE sudah tidak lagi bisa didapatkan, kebebasan untuk beraktifitas dan bekerja antar negara kawasan Eropa tidak lagi dapat dilakukan, hal ini dikarenakan adanya pemberlakuan Visa bagi setiap warga negara Inggris yang beraktivitas di wilayah Eropa (BBC 2020). Meskipun demikian, perbincangan terkait kerjasama free trade dengan negara maju lainnya telah dilaksanakan (BBC 2020), Inggris dan UE tengah berupaya membangun eksistensinya masing-masing.

\section{Kesimpulan}

Kerjasama regional yang dibentuk oleh negara-negara Eropa adalah bentuk dari perkembangan isu dan aktor dalam politik internasional. Sebagai sebuah institusi, UE adalah aktor yang menjadi pihak yang mendorong terciptanya pembangunan ekonomi, sosial budaya dan politik, bahkan dalam berbagai isu lainnya. Permasalahan mengenai kedaulatan suatu negara dalam sebuah institusi regional maupun global adalah hal yang dapat mempengaruhi secara signifikan ketika negara secara individu dan mutlak tidak bisa atau tidak diberikan hak untuk bersuara dalam sebuah organisasi. Dalam hal ini, referendum Inggris dinilai dipengaruhi oleh kedaulatan Inggris yang melemah dalam menentukan kebijakan pada setiap kesepakatan UE, permasalahan signifikan lainnya adalah terkait isu ekonomi serta imigran yang meningkat dikawasan UE sejak tahun 2015. Keputusan Brexit sendiri masih menjadi pertanyaan bagi beberapa pihak, apakah Inggris maupun UE dapat kembali mengembangkan eksistensinya dalam tatanan dunia global.

\section{Daftar Pustaka}

Acharya, Amitav, and Richard Stubbs. 2006. "Theorizing Southeast Asian Relations: an Introduction." The Pacific Review 125-134.

Ayoob, Mohammed. 2002. "Inequality and Theorizing in International Relations: The Case for Subaltern Realism." International Studies Review $27-48$. 
Barkin, J. Samuel. 2006. International Organization: Theories and Institutions. New York: Palgrave Macmillan.

BBC. 2020. BBC News. December 30. Accessed January 22, 2021. https://www.bbc.com/news/uk-politics-32810887.

Beker, Victor. 2014. "The European Debt Crisis: Causes and Consequences." Journal of Stock and Forex Trading 90-120.

Commission, European. 2020. Migration and Home Affairs. January 1. Accessed October 20, 2020. https://ec.europa.eu/home-affairs/what-we-do/policies/asylum_en.

Department of State. 1951. An Analysis of the Schuman Plan. Bulletin, New York: Department of State, Office of Public Affairs.

Eremina, N.V, and A.Y Chikhachev. 2016. "FROM "OPEN DOOR POLICY" TO MIGRANT CRISIS: THE REFORMING OF MIGRATION POLICY IN EUROPEAN AND NATIONAL DIMENSIONS (THE EXAMPLES OF GREAT BRITAIN AND FRANCE)." Comparative Politics Russia 36-61.

European Community. 2019. The European Single Marker. September 19. Accessed January 20, 2021. http://www.ec.europa.eu.

European Union. 2020. The history of the European Union. January 1. Accessed November 1, 2020. https://europa.eu/european-union/index_en.

Fawcett, Louis, and Andrew Hurrel. 1995. Regionalism in World Politics: Regional Organization and International Order. Oxford: Oxford University Press.

Fratzke, Susan. 2015. The Fading Promise of Europe's Dublin System. Brussels: Migration. Research, Brussels: Migration Policy Institute Europe.

Haas, Ernst B. 1958. The Uniting of Europe: Political, Social, and Economic Forces. London: Library of World Affairs.

Holden, Patrick. 2018. Brexit: An international relations perspective. Academic Commentary, England: University of Plymouth.

Independent. 2015. Independent. September 16. Accessed November 7, 2020. https://www.independent.co.uk/.

Jackson, Robert, and George Sorensen. 2003. Introduction to International Relations. England: Oxford university Press.

Kemlu. 2019. Isu-isu Kemanusiaan. April 6. Accessed January 20, 2021. https://kemlu.go.id/. 
-. 2019. Kementerian Luar Negeri Indonesia. April 6. Accessed October 21, 2020.

https://kemlu.go.id/portal/id/read/88/halaman_list_lainnya/isu-isu-ke manusiaan.

Linklater, Andrew, and Hidemi Suganami. 2009. The English School of international Relations. England: Cambridge University Press.

Lombok, Lesza Leonardo. 2014. "Kedaulatan Negara vis a vis Keistimewaan dan Kekebalan Hukum Organisasi Internasional dalam Sebuah Intervensi Kemanusiaan." Pandecta 50-75.

Morgenthau, Hans. 1951. In Defense of the National Interest. New York: Knopf.

Park, Donghyun, Cynthia Castillejos-Petalcorin, and Jungsuk Kim. 2020. ANALYSIS OF BREXIT AND ITS POLICY LESSONS FOR ASIAN. Working Paper, Tokyo: ADBI.

Sampson, Thomas. 2018. "Brexit: The Economics of International Disintegration." The Journal of Economic Perspective 163-184.

Somai, Miklós, and Zsuzsanna Biedermann. 2016. "BREXIT: REASONS AND CHALLENGES." Acta Oeconomica 137-156.

Tidore, Mashita Dewi. 2017. DINAMIKA REFERENDUM INGGRIS DI UNI EROPA. Thesis, Makassar: UNHAS.

UK Parliament. 2013. The EEC and the Single European Act. April 1. Accessed January 20, 2021. https://www.parliament.uk/.

UKEssays. 2018. Impact of Brexit on Regional Integration. November 28. Accessed January 22, 2021. https://www.ukessays.com/essays/society/impact-of-brexit-on-regional -integration.php?vref $=1$.

UNHCR. 1966. Konvensi dan Protokol Mengenai Status Pengungsi. Charter, Jakarta: United Nations.

UNHCR. 2015. Laporan Tren Global Tahunan. Press Release, Jakarta: UNHCR.

Winarno, Budi. 2014. Dinamika Isu-isu Global Kontemporer. Yogyakarta: CAPS.

Zaidi, Syed Haider Ali, Xin-Yu Wang, Sardar Ahmed, Saif UR Rehmen, Muhammad Sajid, Muhammad Hossein Foroozanfar, and Muhammad Ashraf Ali. 2017. "Brexit: A Review of Impact on Future of United Kingdom Outside European Union." International Journal of Modern Research in Management 14-33. 
